\title{
To what extent is the Chinese housing boom driven by competition in the marriage market?
}

\author{
Siyao Yang ${ }^{1}$ (D) Alessandra Guariglia ${ }^{2}$ (D) Nicholas Horsewood ${ }^{2}$
}

Received: 8 October 2018 / Accepted: 3 May 2020 / Published online: 15 June 2020

(c) The Author(s) 2020

\begin{abstract}
We use the 2011 and 2013 waves of the China Household Finance Survey (CHFS) to study the extent to which the acquisition of multiple houses is determined by the presence of male children in the family. We conjecture that, as a result of the very high sex ratio which can be observed in China following the one child policy, Chinese families who have a son may want to acquire additional dwellings to enhance the marriage chances of their son. In support of this argument, we find that families with male children aged 25 or older are most likely to acquire additional houses. This effect is highest in regions characterised by higher sex ratios, especially in rural areas.
\end{abstract}

Keywords China $\cdot$ Children's gender $\cdot$ Acquisition of multiple dwellings $\cdot$ Sex ratios

\section{Introduction}

The Chinese housing market has witnessed a boom over the last two decades. Following the privatization of the housing sector in 1998, home ownership in China has risen substantially, standing at roughly $90 \%$ compared to about $65 \%$ in the US (Glaeser et al., 2017). The increased demand for houses has driven prices up, especially in areas such as Beijing, Shanghai, and Shenzhen. Several households own more than one home and often these houses are unoccupied. One questions therefore what has driven this housing boom, and in particular, the decision of households to acquire multiple homes. The literature on this topic is scant and mainly concentrates on investment ( $\mathrm{Li}$ and $\mathrm{Wu}, 2014)$ and/or speculation as motives for multiple-home ownership (Cao et al., 2018).

Alessandra Guariglia

a.guariglia@bham.ac.uk

Siyao Yang

sy.yang0829@hotmail.com

Nicholas Horsewood

N.J.Horsewood@bham.ac.uk

1 Department of Economics, Muirhead Tower, University of Birmingham, Edgbaston,

Birmingham B15 2TT, UK

2 Department of Economics, University House, University of Birmingham, Edgbaston, Birmingham B15 2TY, UK 
In this paper, we propose an alternative explanation, centered on the role of male children present in the family. This line of research is motivated by literature, which has suggested that due to the unbalanced sex ratio in China, ${ }^{1}$ those parents who have a male child save more in order to improve their son's marriage prospects (Wei and Zhang, 2011). Considering that a house is viewed as a status good in China (Wei et al., 2017), ${ }^{2}$ we extend this literature by investigating the extent to which the acquisition of multiple dwellings may also be a way for families to improve the marriage prospects of their son. Specifically, we investigate the extent to which families with at least one son close to marriage age are more likely to acquire additional houses. Next, we investigate whether the association between having a son and multiple-home acquisition is stronger in those provinces characterized by a more unbalanced sex ratio. This would support our hypothesis that the acquisition of multiple dwellings is driven by a desire to improve sons' marriage prospects.

In order to investigate these issues, we use the 2011 and 2013 waves of the China Household Finance Survey (CHFS) to estimate a model aimed at understanding the determinants of multiple-home acquisition, controlling for demographic, education, and job-related characteristics of the household head, as well as risk attitudes and family income. We find that around $10 \%$ of households acquired an additional house between the two waves of the CHFS. Furthermore, we find that Chinese families with at least one son aged 25 or above have a significantly higher probability of acquiring an additional home. This effect is highest in regions characterized by a high sex ratio, especially in rural areas.

The remaining part of this paper is laid out as follows. Section 2 contains a brief literature review. Section 3 describes our hypotheses. Section 4 illustrates our baseline specifications. Section 5 describes our data and presents some descriptive statistics. Section 6 presents our empirical results and Sect. 7 concludes.

\section{Literature review}

In this section, we first survey the literature on multiple-home ownership in countries other than China. We then provide a brief overview of the housing reforms in China, and describe the literature on multiple-home ownership in China, as well as research relating to son preferences, sex ratios, and home ownership. Finally, we outline our contribution to the literature.

\subsection{Multiple-home ownership in countries other than China}

Multiple-home ownership has become increasingly widespread worldwide. A large empirical literature has emphasized that the proportion of the population owning multiple houses is booming in some countries. For instance, more than $36 \%$ and $22 \%$ of households own additional houses for recreational and business purposes, respectively in Spain and Italy (Sierminska and Doorley, 2013). Similarly, around 20\% of Swedish households and $50 \%$ of

\footnotetext{
1 The sex ratio is defined as the ratio of males to females born in a given province. As a result of the one child policy, and considering Chinese people's preference for sons (Chen et al., 2013), and the wide availability of ultrasound B machines, the sex ratio has become increasingly unbalanced in China (Wei et al., 2017).

2 Wei et al. (2017) argue that: "Housing wealth is a status good because it is one of the sorting variables that affect how a young man (or woman) is ranked relative to his/her competitors". (p. 170).
} 
all Northern European households have access to second houses (Dijst et al., 2005; Müller, 2007). However, there are only few studies on the determinants of multiple-home ownership (Paris, 2009).

Relying on the European Union Survey of Income and Living Conditions (EU SILC) over the period 2003-2006, Norris and Winston (2010) examine the correlation between demographic factors and multiple-home ownership in Ireland. Their first finding is that household wealth affects second-home ownership. Secondly, the authors find that secondhome ownership peaks just before retirement, as it is seen as a sort of retirement plan. Hall et al. (2004) and Brown et al. (2008) also find a significant association between retirement and the acquisition of multiple homes.

Based on the 2011 Eurosystem Household Finance and Consumption Survey (HFCS), which covers household balance sheets of 15 European countries, Arrondel et al. (2014) examine which household characteristics can explain multiple-home ownership. Firstly, they argue that household income is positively associated with both the probability and the value of owning second/third homes. Di et al. (2001) reach a similar conclusion for the US. Secondly, Arrondel et al. (2014) find that the probability of owning multiple homes is positively correlated to inheritance in Europe. Based on data drawn from 12,652 preretirement age households in the US, Cox and Stark (2005) also uncover a significant association between inheritance and multiple-home ownership.

\subsection{Housing reforms in China}

As a result of the transition from a planned economy to a market economy, market mechanisms were introduced into socialist China. In order to stimulate housing consumption, the government created a housing market in the traditional housing system and allowed the housing stock to be privatized. Welfare housing was gradually transformed into commodity housing. These changes affected households' housing acquisition behaviour, as well as the entire socialist housing system in China. As a result, private housing ownership increased drastically: Chamon and Prasad (2010) document that whilst in 1990, only 17\% of Chinese households owned their homes, the corresponding figure in 2005 was $86 \%$. Furthermore, the increased demand for houses has driven prices up, especially in areas such as Beijing, Shanghai, and Shenzhen (Glaeser et al., 2017). Several Chinese households now own more than one house and often these houses are unoccupied.

\subsection{Multiple-home ownership in China}

Although multiple-home ownership has received attention in the US and European countries (Arrondel et al., 2014; Di et al., 2001; Dijst et al., 2005; Cox and Stark, 2005; Müller, 2007; Norris and Winston, 2010; Sierminska and Doorley, 2013), little is known about the situation in China.

Using a survey conducted in 2005, which includes 93 interviewees from Haikou (the capital city of the Hainan province), Wang (2006) analyzes the second-home boom in the city. He argues that because of its superb environmental conditions, Haikou is one of the most popular cities in China where people, and especially those who suffer from M2.5 air pollution in the mainland, acquire second homes. This finding is similar to that in Gallent and Tewdwr-Jones (2018), who also finds that water-side areas in Western countries are attractive to second residential dwelling buyers. Another reason for non-local households to acquire second homes in Haikou is down to the so called 'examination immigration': 
The admission criterion of the 'China college entrance examination' for Hainan students is in fact lower than in mainland areas. This encourages parents to gain Hainan hukou for their college-age children through local housing acquisitions, so that the children can benefit from the local admission criteria.

Hui and Yu (2009) make use of a survey conducted by the Census and Statistics Department (CSD), which covers 13,397 Hong Kong households over the period May-July 2005. The authors explore reasons why Hong Kong residents purchase second homes in mainland China. Specifically, mainland second-home acquisitions are likely to occur among middleaged Hong Kong households. Due to the improved transportation between Hong Kong and the mainland, about 200,000 Hong Kong residents work on mainland China. This makes owning second homes on the mainland convenient. The authors argue that young people are more likely to acquire their first or primary residence in the mainland, while the middle-aged residents prefer second-home ownership. This can be explained bearing in mind that middle-aged households are more constrained by their family responsibilities in Hong Kong.

Feng and Zhou (2004) analyse data drawn from 1,000 questionnaires filled in by Beijing households in 8 representative districts. They report that, due to the very high commuting times in Beijing, $23.7 \%$ of Beijing households own second homes that are close to their workplaces. Lee and Xiao (1998) study the distinct relationship between inheritance and home ownership in China using data from the China Survey on Support Systems for the Elderly in 1992. They find that short-term exchanges between generations involving housing and financial transfers are peculiar to China, while these are not common in other countries. Specifically, elderly Chinese parents are likely to provide financial support for their adult children's home acquisitions.

Based on the 2005 CGSS (China General Social Survey) that covers 26 provinces in China, Huang and Yi (2011) examine the housing acquisition behaviour of Chinese households. They find that public housing has a positive influence on second-home acquisition in China. This is because households having access to public housing only enjoy partial property rights, but are not de facto homeowners. This encourages them to buy secondary real estate of their own. Furthermore, even if the property rights of public housing are possessed by public institutions and work units, households can still benefit from low housing prices. Therefore, public housing reduces the burden on households, enabling them to afford further real estate. This phenomenon is unique to China.

Based on the 2011 wave of the CHFS, Cao et al. (2018) find that households are more likely to own multiple houses when expecting higher capital gains. They also argue that wealthier households are more sensitive to changes in expected capital gains.

\subsection{Son preference, sex ratios and home ownership in China}

The paper closest to ours are $\mathrm{Li}$ and $\mathrm{Wu}$ (2017) and Wei et al. (2017). The former makes use of the 2010 wave of the China Family Panel Survey (CFPS) to study the extent to which having a son is associated with family wealth. They find that having a son has a significant positive effect on various components of family wealth. Specifically, households with a son have a higher probability of owning a house, own more and larger houses, and acquire their houses earlier. Wei et al. (2017) use data from the $20051 \%$ survey of the Chinese population to show that in regions characterised by higher sex ratios, households, and especially those with unmarried sons at home, tend to buy larger houses and to pay a higher price per square meter. 


\subsection{Our contribution}

We advance the literature by analysing, for the first time, the extent to which having a son affects decisions to acquire additional houses. This research question is motivated by the existence of high sex ratios in China, which make it difficult for many men to find a wife (Wei and Zhang, 2011; Wei et al., 2017). As a house is regarded as a status good, households with one or more sons may decide to acquire additional houses for their son(s) in order to enhance their marriage prospects. We build on Li and Wu (2017) by focusing on the determinants of the actual acquisition of additional houses rather than just the ownership of multiple houses, which may have been acquired a long time ago, before the start of the survey. ${ }^{3}$ We then investigate, for the first time, whether the association between sons and the acquisition of multiple dwellings varies according to the age of the son, and whether this phenomenon is more widespread in provinces with higher sex ratios. This part of our work builds on Wei et al. (2017), who show that average home value and size in China vary systematically with local sex ratios.

\section{Hypotheses}

\subsection{General hypothesis on multiple-home acquisition in China}

There is a long history of preference for having baby boys in China (Chen et al., 2013). Although, this preference is no longer popular among young generations and not encouraged by the government, it is still deeply rooted within Chinese traditional cultural values. In this context, having sons is believed to have an impact on households' financial behaviour in China.

Because of the son-preference culture, parents in China typically tend to provide more support to their sons than their daughters, especially on the financial side. Knight et al. (2010) find that Chinese households are motivated to earn more if their child is male. They intend to earn more for their sons because they believe that sons deserve more than daughters. In addition, Chinese families with boys are found to spend more on health relative to families with girls (Song, 2000). The same applies to the share of expenditure on education, given that parents in China have higher expectations from boys in terms of educational achievements (Burgess and Zhuang, 2000). We hypothesise that housing expenditures follow a similar pattern. We therefore hypothesise that:

H1: Families with (a) son(s) are more likely to acquire multiple residential dwellings, compared to families with no son( $(s)$.

\subsection{Multiple-home acquisition and children's marriage status in China}

As a result of the one child policy, the son-preference culture, and the increased availability of ultrasound B machines after the mid-80s, aggressive sex selective abortions took place in China from the mid-1980s onwards (Wei et al., 2017). This has led to a very high sex ratio in the country. Wei and Zhang (2011) argue that families with sons save more in China to enhance their sons' marriage prospects, in a society characterised by an unbalanced sex ratio. A higher wealth level is in fact considered as a great advantage in the

$\overline{3}$ This is made possible by the fact that we have two years of data available. 
marriage market. As a home is seen as a status good in China (Wei et al., 2017), we believe that families with a son close to marriage age are more likely to acquire second homes. ${ }^{4} \mathrm{As}$ a result, we hypothesise that:

H2: Families with (a) son(s) close to marriage age are more likely to acquire multiple residential dwellings, compared to families with nolyounger son(s).

\subsection{Multiple-home acquisition and sex ratios}

If the acquisition of additional houses is motivated by the desire to enhance the marriage prospects of sons, as discussed in Sect. 3.2, then we expect the association between male children close to marriage age and multiple-home acquisition to be stronger in provinces characterised by higher sex ratios. In other words:

H3: Families with (a) son(s) close to marriage age located in provinces characterised by relatively higher sex ratios are more likely to acquire multiple residential dwellings, compared to families located in other provinces.

\section{Baseline models and estimation methodology}

\subsection{Baseline models}

\subsubsection{Testing the effect of children's gender on multiple-home acquisition}

To test the effects of having son(s) on the probability of acquiring additional homes, we estimate the following equation using a Probit model. This follows the approaches of Arrondel et al. (2014) and Huang and Yi (2011):

$$
\operatorname{Pr}\left[\text { Acquiremulti }_{i, t}=1\right]=\Phi\left[\alpha+\beta_{1} \text { Son }_{i, t}+\beta_{2} \text { Daughter }_{i, t}+\beta_{3} X_{i, t}+V_{p}+\varepsilon_{i, t}\right]
$$

The subscript $i$ represents households, and the subscript $t$ represents time. Acquiremulti $i_{i, t}$ is a dummy variable equal to 1 if the household has acquired an additional home between the 2011 and the 2013 waves of the CHFS, and 0 otherwise. ${ }^{5}$

When focusing on the determinants of Acquiremult $i_{i, t}$, the independent variables include $\operatorname{Son}_{i, t}$ (a dummy variable equal to 1 if household $i$ has at least one son at time $t$, and 0 otherwise), which aims at testing the effect of having a son on multiple-home acquisition, as well as some control variables, $X_{i, t}$, which represent a series of socio-demographic factors for household $i$. We also include the dummy Daughter ${ }_{i, t}$, which is equal to 1 if the household has at least one daughter, and 0 otherwise. $V_{p}$ represents a series of provincial dummies, which encompass province-specific house prices, aimed at taking into account the investment opportunity motive for acquiring additional houses. The error term is indicated by $\varepsilon_{i, t}$.

In line with Wei and Zhang (2011), who show that parents in China are willing to increase their saving ratios in order to enhance their sons' marriage prospects, and with

\footnotetext{
4 It should also be noted that, in China, it is the grooms' families who are expected to provide a residence to young couples (Brown et al., 2011).

5 A household is assumed to have acquired an additional property between the 2011 and 2013 waves of the survey if it owned at least one house in both years and if the difference between the number of houses it owned in the two years is greater than or equal to 1 .
} 
our first hypothesis, we expect to observe a positive and significant marginal effect associated with the Son $_{i, t}$ variable. ${ }^{6}$ We remain sceptical about the marginal effect associated with Daughter $_{i, t}$. A positive sign could be explained by the fact that households with a daughter may want to acquire more houses to increase the bargaining power of the daughters in their marriages (Wei and Zhang, 2011). On the other hand, households with a daughter may not need to acquire an additional residential dwelling for the daughter, as daughters in China typically move to their husbands' family houses once married.

Our models control for age, education, household size, migrant status, party membership income, wealth and types of occupation of the head of the household. ${ }^{7}$ Consistent with widespread evidence, we would expect a household with an older, richer and better educated head, having higher political status and local hukou to show a higher probability of acquiring multiple houses (e.g. Hall et al., 2004; Wang, 2006; Norris and Winston, 2010).

We also take the influence of households' risk attitude into consideration. This is indicated by the dummy variable Riskaversion Rit $_{\text {wh }}$ which takes the value of 1 if household $i$ prefers low-risk investments, and 0 otherwise. We expect to observe a positive marginal effect on risk aversion, as housing is a relatively safe asset.

Furthermore, we consider the effect of regional disparities on multiple-home acquisition. To this end, we include provincial dummies in all our models, and also control for a dummy variable, Policyarea $_{i, t}$, which is equal to 1 if the household is located in the three first-tier cities in China (Beijing, Shanghai and Guangzhou), and 0 otherwise. We do not have clear expectations about the sign of this variable. On the one hand, the housing market is booming in those areas, which could lead to a higher incentive for acquiring an additional house. On the other hand, house prices in these areas are very high, which may act as a deterrent to the acquisition of additional dwellings.

\subsubsection{Differentiating the effect of children's age on multiple- home acquisition}

We then investigate the extent to which households' multiple-home acquisition decisions depend on children's age. Following Wei and Zhang (2011), we argue that households with sons are likely to improve their sons' marriage competitiveness by providing additional houses for them. As a result, we expect parents with sons closer to the marriage age to be more likely to acquire additional houses. To test whether this is the case, we estimate Eq. (2), which differentiates children by gender and age:

$$
\begin{aligned}
& \operatorname{Pr}\left[\text { Acquiremulti }_{i, t}=1\right]=\Phi\left[\alpha+\beta_{1} \text { Son } 12_{i, t}+\beta_{2} \text { Son } 13 \_24_{i, t}+\beta_{3} \operatorname{Son} 25_{i, t}\right. \\
& \left.\quad+\beta_{4} \text { Daughter } 12_{i, t}+\beta_{5} \text { Daughter } 13 \_24_{i, t}+\beta_{6} \text { Daughter } 25_{i, t}+\beta_{7} X_{i, t}+V_{p}+\varepsilon_{i, t}\right]
\end{aligned}
$$

The subscript $i$ represents households, and $t$ represents time. Son $12_{i, t}$ is a dummy equal to 1 if the household has a son aged at least 12 , and 0 otherwise. Son $13 \_24_{i, t}$ is a dummy equal to 1 if the household has a son aged 13 to 24 , and 0 otherwise. Son $25_{i, t}$ is a dummy equal to 1 if the household has a son aged at least 25 , and 0 otherwise. Similar age-related dummies are included for daughters. Other control variables are the same as in Eq. (1).

\footnotetext{
6 As discussed in Sect. 4.2, all our models are estimated using a Probit estimator. As such, we focus on marginal effects rather than coefficients.

7 Income and wealth are included to indirectly proxy for the investment opportunity motive for acquiring additional homes. Table A1 in the Appendix presents all variables used in our models and their definitions.
} 
In line with Hypothesis 2, we expect to observe positive and significant marginal effects associated with Son $13 \_24_{i, t}$ and Son $25_{i, t}$, with the marginal effect associated with the latter dummy being the highest, as sons aged at least 25 are the closest to marriage age.

\subsubsection{Testing the effect of living in high sex-ratio provinces on multiple-home acquisition}

In order to test whether the effect of having a son close to marriage age on the likelihood to acquire multiple homes is higher for households based in provinces with high sex ratios, we estimate the following two Equations:

$$
\begin{aligned}
& \operatorname{Pr}\left[\text { Acquiremulti }_{i, t}=1\right]=\Phi\left[\alpha+\beta_{1} \text { High }_{i, t}+\beta_{21} \text { High }_{i, t} \text { Son }_{i, t}\right. \\
& +\beta_{22}\left(1-\text { High }_{i, t}\right) \text { Son }_{i, t}+\beta_{31} \text { High }_{i, t} \text { Daughter }_{i, t} \\
& \left.+\beta_{32}\left(1-\text { High }_{i, t}\right) \text { Daughter }_{i, t}+\beta_{4} X_{i, t}+V_{p}+\varepsilon_{i, t}\right]
\end{aligned}
$$

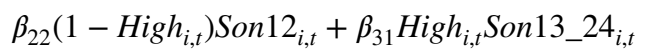

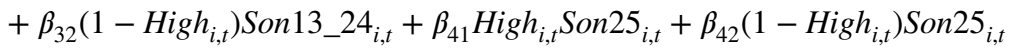

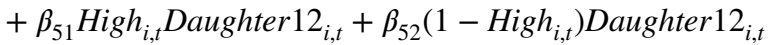

$$
\begin{aligned}
& +\beta_{61} \text { High }_{i, t} \text { Daughter13_24 } 4_{i, t}+\beta_{62}\left(1-H i g h_{i, t}\right) \text { Daughter13_24 }{ }_{i, t}
\end{aligned}
$$

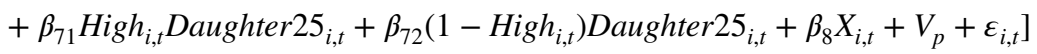

where $H i g h_{i, t}$ is a dummy variable equal to 1 if household $i$ lives in a province with high sex ratio at time $t$, and 0 otherwise. In line with Hypothesis 3, we expect to observe the following relationship in Eq. (3): $\beta_{21}>\beta_{22}>0$. Similarly, in Eq. (4), we expect to observe: $\beta_{31}>\beta_{32}>0$ and $\beta_{41}>\beta_{42}>0$.

\subsection{Estimation methodology}

Because our dependent variable is binary, all our models are estimated using a Probit estimator, and marginal effects are reported and discussed in all Tables. Considering that our dependent variable represents the acquisition of additional dwellings and is calculated as a dummy equal to 1 if the difference between the number of houses owned by the household in the 2013 and 2011 waves of the CHFS is greater than or equal to 1, only 2013 data are effectively used in estimation. All our regressions are therefore cross-sectional, and the subscript $t$ in all equations corresponds to 2013 .

\section{Data and summary statistics}

\subsection{Data}

We use the 2011 and 2013 waves of the China Household Finance Survey (CHFS), a biannual survey collected at the Southwestern University of Finance and Economics in 
Chengdu (China). ${ }^{8}$ The survey is based on a three-stage stratified random sampling design. Specifically, at first, counties are randomly selected among 29 Chinese provinces. Second, communities are randomly selected within each county. Finally, both urban and rural households are randomly selected within each community. The final sample, which is representative of the Chinese population, and contains accurate and detailed information on households' demographic characteristics, their financial and non-financial assets, and their business activities, contained 8,438 households in 2011 (Gan et al., 2014). In 2013, the survey was expanded to 28,413 households to enhance representativeness at the provincial level.

Bearing in mind that our Acquiremulti variable is calculated as the difference in the number of dwellings owned in the two waves, only the 2013 wave is used in estimation. Moreover, because our focus is on multiple-home ownership, we only consider households which were already home owners in 2011. We also drop those observations with missing values for any of the regression variables in our models. Finally, in order to control for extreme values, we set the values of wealth and income in the top and bottom $1 \%$ of the distribution to missing. After the above adjustments, our final dataset includes 5,815 observations over the year 2013 .

\subsection{Summary statistics}

Table 1 contains descriptive statistics for our regression variables. We observe that $10.2 \%$ of our observations acquired an additional house between 2011 and 2013. Furthermore, $53.9 \%$ of the observations in our sample have at least one son, whist $31.9 \%$ have at least one daughter. Focusing on socio-economic characteristics of the heads of the households included in our sample, we can see that the average age is 52.7 and that $7.4 \%$ of the household heads have a college education. About $5 \%$ of the household head are migrants, $31.8 \%$ are employed, $25.8 \%$ work in agriculture, and $16.0 \%$ are retired. $66.4 \%$ of our households live in urban areas.

Table 2 presents means of all our regression variables for households who acquired an additional house between the two waves and households who did not. We can see that $62.0 \%(37.5 \%)$ of acquirers have a son (daughter), while the corresponding figure for nonacquirers is $53.0 \%(31.2 \%)$. Both differences are statistically significant, and suggest that people who acquire second homes are more likely to have children, particularly sons. This provides some preliminary support for our Hypothesis 1.

Looking at the age of children, acquirers are more likely to have sons aged between 13 and 24 and sons aged 25 or above, which is in line with the predictions of Hypothesis 2. Acquirers are also more likely to have daughters aged below 13. The differences among other age categories are not statistically significant. In terms of other variables, acquirers are typically younger, richer, and more likely to have a college degree, and a larger household. They are also more likely to be party members, employed, or self-employed. Finally, acquirers seem to be less likely to be risk-averse than non-acquirers.

\footnotetext{
${ }^{8}$ We do not use the 2015 wave of the CHFS as information on the migrant status of the household, which is an important determinant of house purchase, is missing in that wave.
} 
Table 1 Sample means and standard deviations (in parentheses)

\begin{tabular}{lc}
\hline Variables & Mean (Std. Dev) \\
\hline Acquiremulti & $0.102(0.30)$ \\
Son & $0.539(0.50)$ \\
Daughter & $0.319(0.47)$ \\
Son12 & $0.125(0.33)$ \\
Son13_24 & $0.210(0.41)$ \\
Son25 & $0.234(0.42)$ \\
Daughter12 & $0.094(0.29)$ \\
Daughter13_24 & $0.164(0.37)$ \\
Daughter25 & $0.080(0.27)$ \\
Age & $52.719(13.16)$ \\
College & $0.074(0.26)$ \\
Household size & $3.562(1.61)$ \\
Migrant & $0.048(0.21)$ \\
Party membership & $0.195(0.40)$ \\
Income & $0.552(0.60)$ \\
Wealth & $1.469(2.58)$ \\
Employee & $0.318(0.47)$ \\
Selfemployed & $0.090(0.29)$ \\
Agriculture & $0.258(0.44)$ \\
Other job types & $0.038(0.19)$ \\
Retired & $0.160(0.37)$ \\
Riskaversion & $0.715(0.45)$ \\
Policyareas & $0.082(0.28)$ \\
Urban & $0.664(0.47)$ \\
High & $0.571(0.49)$ \\
Observations & 5815 \\
\hline
\end{tabular}

Note: Precise definitions of all variables can be found in Table A1 in the Appendix

\section{Empirical results}

\subsection{Multiple-home acquisition differentiating children by gender and age}

Column 1 of Table 3 reports Probit estimates of Eq. (1). We can see that neither the marginal effect associated with the presence of sons, nor that associated with daughters are statistically significant. These findings do not support our Hypothesis 1 and seem to suggest that, controlling for other factors, multiple-home acquisitions in China are not associated with the presence of children. In line with the literature (e.g. Norris and Winston, 2010; Arrondel et al., 2014), both income and wealth are positively associated with the acquisition of additional houses. Furthermore, families whose head is self-employed and/or a party member are both more likely to acquire additional houses, as are larger households.

Column 2 presents Probit estimates of Eq. (2), whereby both sons and daughters are differentiated in the following age groups: below 13, between 13 and 24, and 25 and above. We can see that having a male child aged 25 or above is associated with a 3.6 percentage point higher chance to acquire an additional house, whilst having a son aged 13 to 24 is 
Table 2 Descriptive statistics differentiating households on the basis of whether or not they acquired an additional house between 2011 and 2013

\begin{tabular}{|c|c|c|c|}
\hline & (1) & (2) & (3) \\
\hline & $\begin{array}{l}\text { No additional } \\
\text { house acquired }\end{array}$ & $\begin{array}{l}\text { Acquired an } \\
\text { additional house }\end{array}$ & Difference \\
\hline Son & 0.530 & 0.620 & $-0.091 * * *$ \\
\hline Daughter & 0.312 & 0.375 & $-0.062 * * *$ \\
\hline Son12 & 0.125 & 0.118 & 0.008 \\
\hline Son13_24 & 0.206 & 0.249 & $-0.043 * *$ \\
\hline Son 25 & 0.226 & 0.303 & $-0.076^{* * *}$ \\
\hline Daughter12 & 0.090 & 0.133 & $-0.043 * * *$ \\
\hline Daughter13_24 & 0.163 & 0.178 & -0.016 \\
\hline Daughter25 & 0.079 & 0.094 & -0.015 \\
\hline Age & 52.956 & 50.644 & $2.312 * * *$ \\
\hline College & 0.073 & 0.087 & -0.015 \\
\hline Household size & 3.508 & 4.035 & $-0.528 * * *$ \\
\hline Migrant & 0.048 & 0.052 & -0.004 \\
\hline Party membership & 0.190 & 0.237 & $-0.047 * * *$ \\
\hline Income & 0.525 & 0.788 & $-0.264 * * *$ \\
\hline Wealth & 1.373 & 2.315 & $-0.942 * * *$ \\
\hline Employee & 0.312 & 0.371 & $-0.060 * * *$ \\
\hline Selfemployed & 0.085 & 0.141 & $-0.057 * * *$ \\
\hline Agriculture & 0.261 & 0.235 & 0.025 \\
\hline Other job types & 0.039 & 0.029 & 0.011 \\
\hline Retired & 0.163 & 0.131 & $0.032 * *$ \\
\hline Riskaversion & 0.723 & 0.645 & $0.078 * * *$ \\
\hline Policyareas & 0.081 & 0.097 & -0.016 \\
\hline Urban & 0.663 & 0.676 & -0.013 \\
\hline High & 0.568 & 0.597 & -0.028 \\
\hline Observations & 5220 & 595 & - \\
\hline
\end{tabular}

Note: $* * *$ denotes statistical significance at $1 \%$ level; $* *$ denotes statistical significance at $5 \%$ level; $*$ denotes statistical significance at $10 \%$ level. Precise definitions of all variables can be found in Table A1 in the Appendix

associated with a 2.1 percentage point higher chance. The latter effect is, however, only marginally significant. These findings, which support our second hypothesis, suggest that the acquisition of multiple houses may indeed be a way to enhance the marriage chances of sons in a world characterised by unbalanced sex ratios.

We also observe that having a son aged less than 13 is associated with a 2.8 percentage point lower chance of acquiring an additional house: This may be explained considering that parents of very young sons may prefer to save the money for the education of the child. By contrast, having a daughter aged below 13 is associated with a 2.5 percentage point higher chance of acquiring an additional house. This association, which can be explained considering that families with a young daughter may acquire an additional house to 
Table 3 Determinants of the probability of acquiring multiple homes differentiating households on the basis of the child's gender and age (marginal effects)

\begin{tabular}{|c|c|c|c|}
\hline & (1) & (2) & (3) \\
\hline & Kids; dy/dx (z-value) & Age; dy/dx (z-value) & Legal Age; dy/dx (z-value) \\
\hline Son & $0.005(0.54)$ & - & - \\
\hline Daughter & $0.008(0.80)$ & - & - \\
\hline Son12 & - & $-0.028 * *(-1.98)$ & $-0.025^{*}(-1.77)$ \\
\hline Son13_24/21 & - & $0.021 *(1.89)$ & $0.023 *(1.89)$ \\
\hline Son $25 / 22$ & - & $0.036 * * *(2.84)$ & $0.037 * * *(3.14)$ \\
\hline Daughter12 & - & $0.025 *(1.70)$ & $0.028 *(1.91)$ \\
\hline Daughter13_24/19 & - & $0.010(0.88)$ & $0.009(0.69)$ \\
\hline Daughter25/20 & - & $0.012(0.79)$ & $0.017(1.55)$ \\
\hline Age & $-0.000(-0.91)$ & $-0.001 *(-1.89)$ & $-0.001 *(-1.80)$ \\
\hline College & $-0.019(-1.18)$ & $-0.017(-1.02)$ & $-0.016(-0.96)$ \\
\hline Household size & $0.013 * * *(4.50)$ & $0.009 * * *(2.91)$ & $0.009 * * *(2.90)$ \\
\hline Migrant & $-0.002(-0.10)$ & $0.003(0.16)$ & $0.003(0.15)$ \\
\hline Party membership & $0.021 * *(2.05)$ & $0.022 * *(2.12)$ & $0.022 * *(2.12)$ \\
\hline Household income & $0.041 * * *(5.85)$ & $0.039 * * *(5.56)$ & $0.039 * * *(5.55)$ \\
\hline Household wealth & $0.005 * * *(3.35)$ & $0.005 * * *(3.40)$ & $0.005 * * *(3.40)$ \\
\hline Employee & $0.024(1.64)$ & $0.023(1.58)$ & $0.022(1.54)$ \\
\hline Selfemployed & $0.040 * *(2.31)$ & $0.041 * *(2.35)$ & $0.040 * *(2.30)$ \\
\hline Agriculture & $0.011(0.71)$ & $0.009(0.58)$ & $0.009(0.57)$ \\
\hline Other job types & $-0.007(-0.28)$ & $-0.008(-0.33)$ & $-0.009(-0.37)$ \\
\hline Retired & $0.018(1.07)$ & $0.022(1.30)$ & $0.023(1.34)$ \\
\hline Riskaversion & $-0.014(-1.57)$ & $-0.015 *(-1.74)$ & $-0.015^{*}(-1.73)$ \\
\hline Policyareas & $-0.026(-0.82)$ & $-0.029(-0.92)$ & $-0.030(-0.95)$ \\
\hline Urban & $-0.006(-0.53)$ & $-0.007(-0.63)$ & $-0.007(-0.61)$ \\
\hline Observations & 5815 & 5815 & 5815 \\
\hline
\end{tabular}

Notes: $* * *$ denotes statistical significance at $1 \%$ level; ** denotes statistical significance at $5 \%$ level;* denotes statistical significance at $10 \%$ level. Son13_24/21 is a dummy equal to 1 if the family has a son aged 13 to 24 (column 2) or 13 to 21 (column 3). Daughter13_24/19 is a dummy equal to 1 if the family has a daughter aged 13 to 24 (column 2) or 13 to 19 (column 3). Son25/22 is a dummy equal to 1 if the family has a son aged 25 or more (column 2) or 22 or more (column 3). Daughter25/20 is a dummy equal to 1 if the family has a daughter aged 25 or more (column 2) or 20 or more (column 3). Definitions of all other variables can be found in Table A1 in the Appendix. All models were estimated using a Probit estimator. Provincial dummies are included in all specifications, but not reported for brevity

enhance their daughter's bargaining power once she gets married (Wei and Zhang, 2011), is, however, only marginally significant. ${ }^{9}$

Focusing on other control variables, as in column 1, we observe that richer families, with self-employed heads who are also party members are more likely to acquire additional

\footnotetext{
${ }^{9}$ It is also noteworthy that when differentiating provinces with high sex ratios from provinces with low sex ratios, the marginal effect associated with the presence of young daughters is no longer significant in either type of province. In addition, that same marginal effect is insignificant both in rural and urban areas (see Tables 4 and 5).
} 
houses, whilst a larger household size is also linked with a higher chance of acquiring an additional dwelling.

Colum 3 of Table 3 reports results where the legal marriage ages for males (22) and females (20) are considered instead of the threshold of 25. Specifically, the age categories for males (females) are less than 13, 13 to 21 (13 to 20), and 22 (20) and above. ${ }^{10}$ The results are very similar to those reported in column $2 .{ }^{11}$

\subsection{Does living in a high sex-ratio province make a difference?}

Table 4 presents Probit estimates of Eqs. (3) and (4). ${ }^{12}$ High-sex ratio provinces are defined as those provinces with sex ratios falling in the top half of the distribution. ${ }^{13}$ Sex ratios are calculated at birth and are taken from the 2010 Population Census (National Bureau of Statistics, 2010). Focusing on column 1, we observe that the son and daughter dummy variables never show statistically significant marginal effects in both high-sex ratio provinces and other provinces.

Column 2 differentiates children by age using 25 as the marriage age and column 3 uses instead the legal marriage age for males and females. Focusing on column 2 (3), we can see that having a son aged 25 (22) or above is associated with a 5.0 (4.8) percentage point higher chance of acquiring an additional dwelling in the regions with the highest sex ratios. Theses findings, which are consistent with Hypothesis 3, suggest that, especially in regions characterised by high sex ratios, households with a son close to marriage age are more likely to acquire additional houses, to enhance their son's chance in the marriage market.

In regions characterised by relatively low sex ratios, having a son aged between 13 and 24 , or 25 and above does not affect the chance of acquiring an additional dwelling. Yet, in these regions, having a son younger than 13 is associated with a 3.6 percentage point (column 2) or 3.3 percentage point (column 3 ) lower chance of acquiring an additional house. This could be explained bearing in mind that in regions with low sex ratios, where the competition for marriage is less fierce, parents may prefer to use their savings to provide a better education to their young son. As a result, they are less likely to acquire additional houses. To justify this claim, we observe that in regions with low sex ratios, education expenditure is $432.217 \mathrm{RMB}$ higher than in provinces characterized by high sex ratios. ${ }^{14}$ This difference corresponds to about $5.3 \%$ of the average education expenditure $(8146.249$ $\mathrm{RMB}$ ) in China.

\footnotetext{
${ }^{10}$ In our preferred specifications, we chose 25 as the age of marriage, as the majority of Chinese people tend to get married later than the legal age. For instance, based on the 2013 wave of the China Household Finance Survey, only $14.57 \%$ (13.37\%) of females (males) aged 20 (22) were married.

11 For robustness, we have verified whether the presence of sons in general and of sons in particular age groups affect the probability of owning (rather than acquiring) more than one house. The results, which are not reported for brevity, but available upon request, were very similar to those in Table 3. It would also have been interesting to investigate the extent to which the birth of a son or the transiting of a son into marriage age relates to the probability of acquiring additional houses. Yet, due to insufficient observations in our sample, we were unable to carry out this test.

12 It should be noted that because these models include a dummy equal to 1 in high-sex ratio provinces, and 0 otherwise, individual provincial dummies were not included.

13 These provinces, with the corresponding sex ratios in parentheses, are: Gansu (117.37); Fujian (125.59); Hunan (123.23); Anhui (128.64); Hebei (114.88); Jiangsu (116.24); Guangdong (120.34); Shaanxi (115.33); Henan (117.77); Sichuan (111.64); Hubei (124.09); Guangxi (122.68); Jiangxi (122.84); and Chongqing (112.51). Inner Mongolia, Yunan, and Xinjiang are not available in our dataset.

${ }^{14}$ We measure education expenditure making use of the following question in the CHFS questionnaire (G1016b): "What was the amount spent on the child's education? (unit: RMB)".
} 


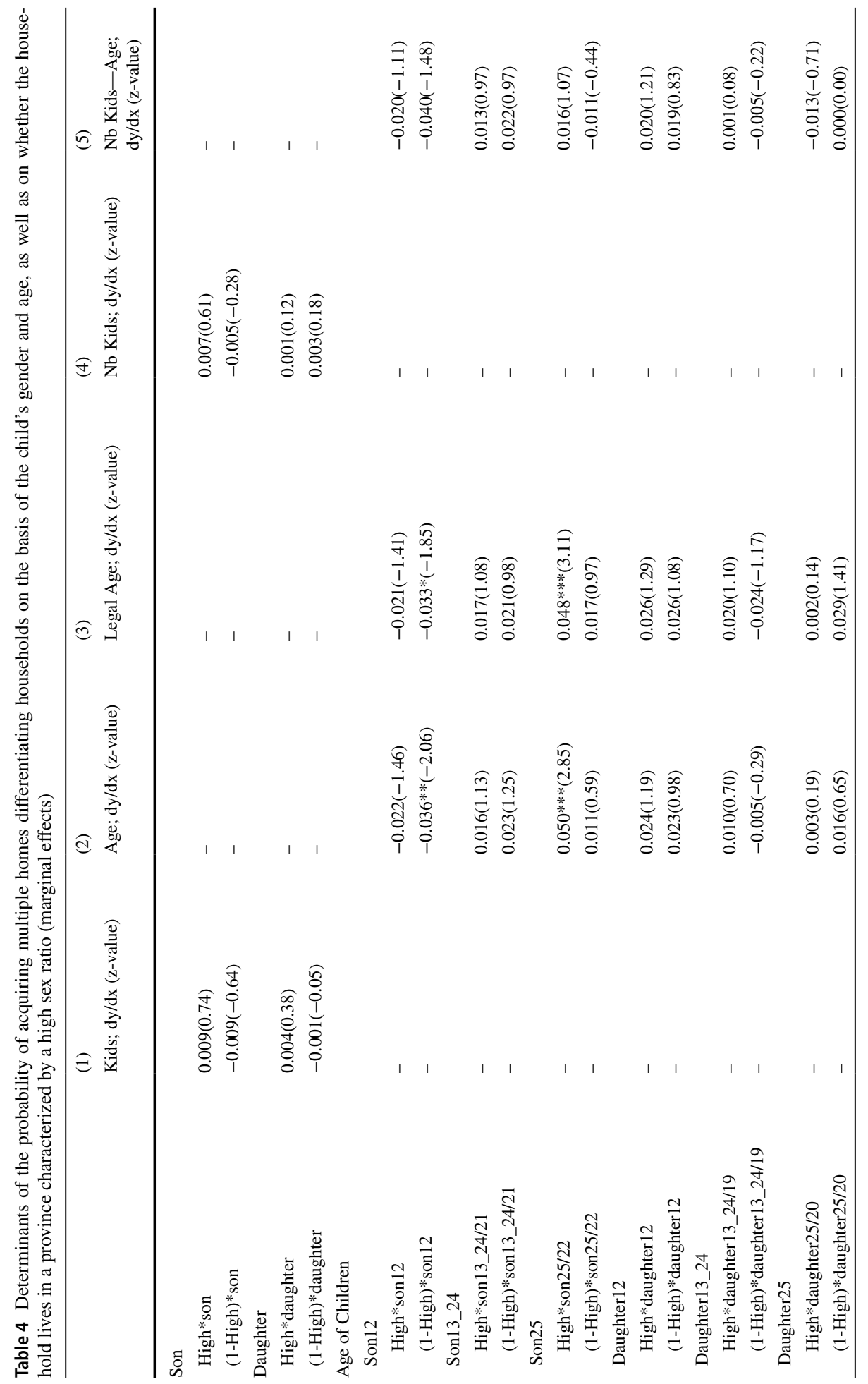




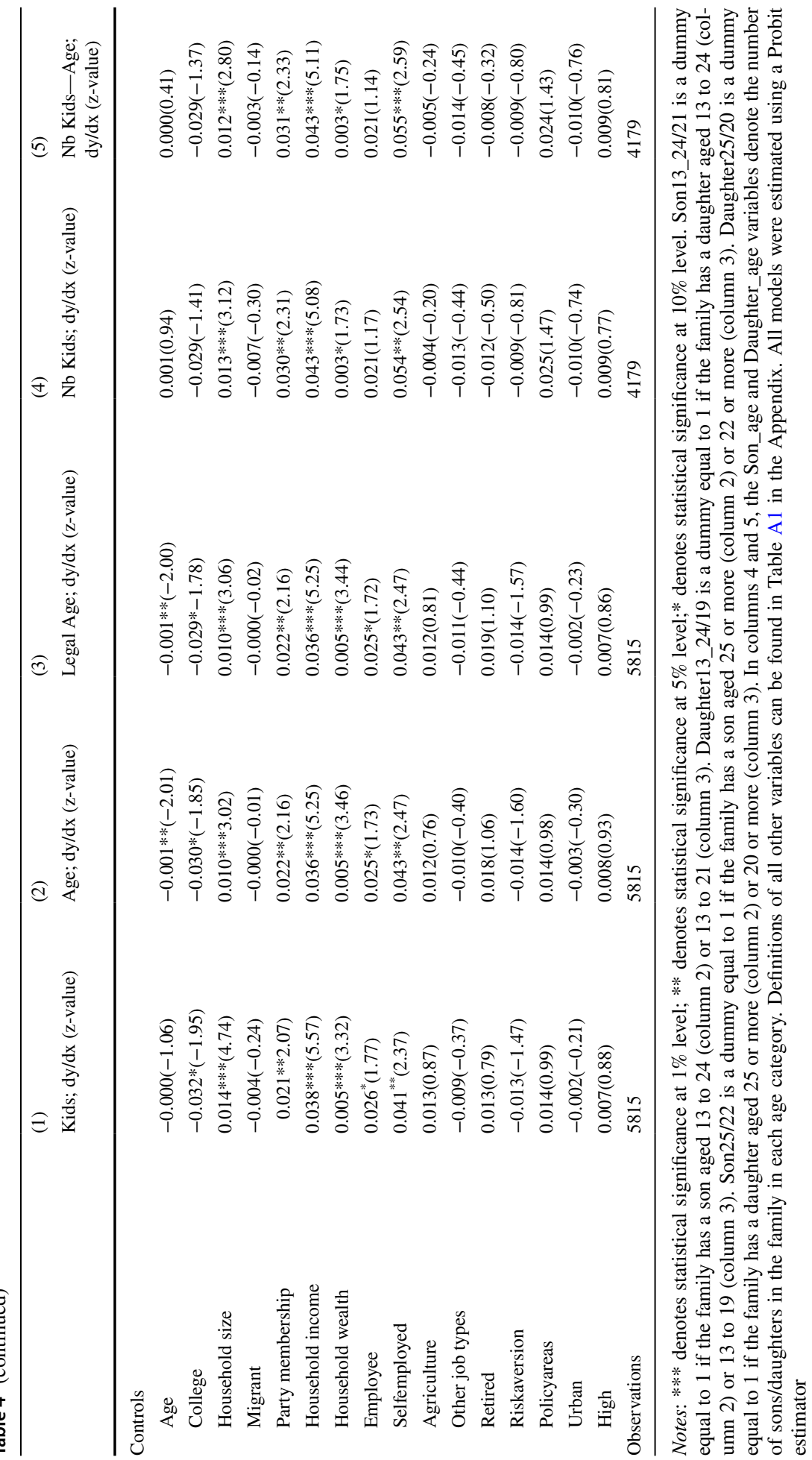


Table 5 Determinants of the probability of acquiring multiple homes differentiating households on the basis of the child's gender and age, as well as on whether the household lives in a province characterized by a high sex ratio (marginal effects)—Urban/Rural households

\begin{tabular}{|c|c|c|c|c|}
\hline & \multicolumn{2}{|l|}{ Urban households } & \multicolumn{2}{|l|}{ Rural households } \\
\hline & (1) & (2) & (3) & (4) \\
\hline & Kids; dy/dx (z-value) & Age; dy/dx (z-value) & Kids; dy/dx (z-value) & Age; dy/dx (z-value) \\
\hline \multicolumn{5}{|l|}{ Son } \\
\hline High*son & $-0.005(-0.30)$ & - & $0.036^{* *}(2.00)$ & - \\
\hline$(1-$ High $) *$ son & $-0.010(-0.64)$ & - & $-0.016(-0.53)$ & - \\
\hline \multicolumn{5}{|l|}{ Daughter } \\
\hline High*daughter & $0.004(0.25)$ & - & $-0.002(-0.14)$ & - \\
\hline (1-High)*daughter & $-0.007(-0.40)$ & - & $0.016(0.50)$ & - \\
\hline \multicolumn{5}{|l|}{ Age of Children } \\
\hline \multicolumn{5}{|l|}{ Son 12} \\
\hline High*son 12 & - & $-0.035 *(-1.93)$ & - & $0.003(0.09)$ \\
\hline$(1$-High)*son 12 & - & $-0.041 * *(-2.16)$ & - & $-0.026(-0.65)$ \\
\hline \multicolumn{5}{|l|}{ Son13_24 } \\
\hline High*son13_24 & - & $0.002(0.09)$ & - & $0.040 *(1.81)$ \\
\hline$(1$-High)*son13_24 & - & $0.012(0.58)$ & - & $0.032(0.88)$ \\
\hline \multicolumn{5}{|l|}{ Son 25} \\
\hline High*son25 & - & $0.042 *(1.74)$ & - & $0.060 * *(2.39)$ \\
\hline$(1-$ High $) * \operatorname{son} 25$ & - & $0.015(0.70)$ & - & $-0.017(-0.50)$ \\
\hline \multicolumn{5}{|l|}{ Daughter12 } \\
\hline High*daughter12 & - & $0.022(0.86)$ & - & $0.027(0.78)$ \\
\hline$(1-$ High $) *$ daughter12 & - & $0.016(0.61)$ & - & $0.040(0.71)$ \\
\hline \multicolumn{5}{|l|}{ Daughter13_24 } \\
\hline High*daughter13_24 & - & $0.010(0.51)$ & - & $0.003(0.13)$ \\
\hline$(1$-High)*daughter13_24 & - & $-0.003(-0.16)$ & - & $-0.030(-0.87)$ \\
\hline \multicolumn{5}{|l|}{ Daughter25 } \\
\hline High*daughter25 & - & $-0.003(-0.13)$ & - & $0.006(0.22)$ \\
\hline$(1-$ High $) *$ daughter 25 & - & $-0.009(-0.35)$ & - & $0.093(1.46)$ \\
\hline \multicolumn{5}{|l|}{ Controls } \\
\hline Age & $-0.000(-0.65)$ & $-0.001(-1.45)$ & $-0.001(-0.74)$ & $-0.001(-1.04)$ \\
\hline College & $-0.032 *(-1.86)$ & $-0.029 *(-1.73)$ & - & - \\
\hline Household size & $0.015^{* * *(3.62)}$ & $0.011^{* *}(2.42)$ & $0.011 * * *(2.69)$ & $0.008 *(1.71)$ \\
\hline Migrant & $-0.003(-0.15)$ & $0.002(0.08)$ & $-0.006(-0.07)$ & $-0.001(-0.01)$ \\
\hline Party membership & $0.019(1.61)$ & $0.020 *(1.65)$ & $0.025(1.24)$ & $0.026(1.27)$ \\
\hline Household income & $0.031 * * *(3.95)$ & $0.031^{* * *}(3.82)$ & $0.054 * * *(3.63)$ & $0.050^{* * *}(3.33)$ \\
\hline Household wealth & $0.008^{* * *}(4.50)$ & $0.008^{* * *}(4.52)$ & $-0.003(-0.95)$ & $-0.002(-0.72)$ \\
\hline Employee & $0.025(1.45)$ & $0.025(1.47)$ & $0.026(0.90)$ & $0.024(0.82)$ \\
\hline Selfemployed & $0.026(1.28)$ & $0.029(1.44)$ & $0.089 * *(2.57)$ & $0.090 * * *(2.60)$ \\
\hline Agriculture & $0.004(0.18)$ & $0.004(0.17)$ & $0.027(1.11)$ & $0.025(1.03)$ \\
\hline Other job types & $-0.018(-0.60)$ & $-0.017(-0.60)$ & $0.005(0.11)$ & $0.004(0.08)$ \\
\hline Retired & $0.005(0.27)$ & $0.010(0.54)$ & $0.077(1.55)$ & $0.077(1.55)$ \\
\hline Riskaversion & $-0.012(-1.12)$ & $-0.014(-1.29)$ & $-0.013(-0.84)$ & $-0.013(-1.85)$ \\
\hline Policyareas & $-0.004(-0.18)$ & $0.004(-0.20)$ & $0.032 *(1.66)$ & $0.034 *(1.76)$ \\
\hline High & $0.020 *(1.94)$ & $0.021^{* *}(2.05)$ & $-0.017(-1.03)$ & $-0016(-0.97)$ \\
\hline Observations & 3861 & 3861 & 1947 & 1947 \\
\hline
\end{tabular}

Notes: $* * *$ denotes statistical significance at $1 \%$ level; $* *$ denotes statistical significance at $5 \%$ level; $*$ denotes statistical significance at $10 \%$ level. Definitions of all variables can be found in Table A1 in the Appendix. All models were estimated using a Probit estimator 
Finally, the marginal effects reported in columns 2 and 3 of Table 4 show that having a daughter, regardless of her age, and regardless of the type of region the family lives in, does not affect the likelihood of acquiring an additional dwelling. It is also interesting to note that the marginal effects associated with the high-sex ratio dummies are never statistically significant. The marginal effects associated with the other control variables are similar to those observed in Table 3.

It could be that what determines multiple dwelling acquisition is the number of children/ sons in the family and the number of children/sons at the marriage age rather than the presence of children in relevant groups. To test whether this is the case, in columns 4 and 5 of Table 4, we have replaced the children dummies in our models with numerical variables denoting the number of children in relevant groups. The results suggest that none of the variables denoting number of sons/daughters in general and in each age category attract statistically significant marginal effects. Hence, we conclude that what matters is not the number of children in given categories, but simply the presence of at least one child in a given group.

\subsection{Are rural areas different from urban areas?}

Lei and Pals (2011) show that son preferences are weaker in cities, which could lead to a weaker association between the presence of sons and the likelihood to purchase additional houses. To see whether this is the case, we next test whether there are any differences in our results across urban and rural areas.

Table 5 reports estimates of our main specifications separately for rural and urban samples. The estimates of Eq. (3) are presented in column 1 for urban households and column 3 for rural households, whilst the estimates of Eq. (4) appear in columns 2 and 4, for urban and rural households respectively. Focusing on columns 1 and 3, we observe that only in rural areas, having a son is associated with a higher chance of acquiring an additional house in provinces with high sex ratio (column 3). Specifically, having a son is associated with a 3.6 percentage point higher chance of acquiring an additional dwelling.

Next, differentiating the children by age, we observe that in rural areas characterised by a high sex ratio, having a son aged 25 or above is associated with a 6.0 percentage point higher chance of acquiring an additional house (column 4). The corresponding percentage in urban areas is much smaller (4.2 percentage points, column 2). It is also noteworthy that, in rural areas with high sex ratios, the presence of a son aged 13 to 24 is also associated with a 4.0 percentage point higher chance of acquiring an additional house.

Furthermore, in urban areas having a son aged 12 or younger is associated with a lower chance of acquiring an additional house (column 2). This effect is apparent in all types of provinces, but is only marginally significant and relatively small in high-sex ratio provinces. As discussed in Sect. 6.2, this pattern can be explained bearing in mind that parents with young sons may prefer to spend their money on the education of their sons, especially in provinces with relatively low sex ratio, where the competition for marriage is less fierce, and in urban areas where the son preference is weaker. Finally, the marginal effects associated with the presence of female children in the family are never statistically significant regardless of the age of the child and location. 


\section{Conclusions}

We have used the 2011 and 2013 waves of the China Household Finance Survey to test, for the first time, the extent to which the acquisition of multiple houses is determined by the presence of male children in the family. We have differentiated children according to age and have assessed the extent to which living in a high-sex ratio region makes a difference. We have found that families with sons aged 25 or older are most likely to acquire additional houses. This effect is highest in regions characterised by higher sex ratios, especially in rural areas. Our findings complement those in $\mathrm{Li}$ and $\mathrm{Wu}$ (2017) who find that households with a son have a higher probability of owning a house, own more and larger houses, and acquire their houses earlier. They also complement Wei et al. (2017) who show that in regions characterised by higher sex ratios, households, and especially those with unmarried sons at home, tend to buy larger houses and to pay a higher price per square meter.

Our results suggest that Chinese families' son-preference culture may be an explanation for the housing boom in China, a country characterised by unbalanced sex ratios. The termination of the one child policy in 2016 is likely to slowly restore the sex ratio to normal levels. When this happens, households may have a lower incentive to acquire additional dwellings to enhance their sons' marriage prospects. That may contribute to a slowing down of the housing boom.

Yet, the improvement of sons' marriage prospects is not the only reason why Chinese people acquire multiple homes. The investment motive for acquiring houses plays in fact an important role too. Bearing in mind the very high saving rate characterising Chinese households (Choi et al., 2017) and the substantial increase in house prices observed in recent years, which allows home owners to benefit from substantial capital gains ( $\mathrm{Li}$ and $\mathrm{Wu}, 2014$; Cao et al., 2018), housing represents a lucrative and popular type of investment in China. The investment motive for acquiring additional houses in China is strong also because the relatively poorly developed financial sector offers few alternative investment channels. Moreover, Chinese households find it difficult to invest overseas due to the stringent capital controls imposed by the government (Liu and Xiong, 2018). A thorough study of other explanations for why Chinese households tend to acquire multiple homes is on the agenda for future research.

Open Access This article is licensed under a Creative Commons Attribution 4.0 International License, which permits use, sharing, adaptation, distribution and reproduction in any medium or format, as long as you give appropriate credit to the original author(s) and the source, provide a link to the Creative Commons licence, and indicate if changes were made. The images or other third party material in this article are included in the article's Creative Commons licence, unless indicated otherwise in a credit line to the material. If material is not included in the article's Creative Commons licence and your intended use is not permitted by statutory regulation or exceeds the permitted use, you will need to obtain permission directly from the copyright holder. To view a copy of this licence, visit http://creativecommons.org/licenses/by/4.0/.

\section{Appendix}

Table A1 contains precise definitions of the main variables used in the paper. 
Table A1 Definition of the main variables used

\begin{tabular}{|c|c|}
\hline Variable Name & Description \\
\hline \multicolumn{2}{|c|}{ Dependent Variable } \\
\hline Acquiremulti & $\begin{array}{l}\text { Dummy variable equal to } 1 \text { if the household has acquired an additional property } \\
\text { between the } 2011 \text { and } 2013 \text { waves of the survey, and } 0 \text { otherwise }^{*}\end{array}$ \\
\hline \multicolumn{2}{|c|}{ Independent Variables Related to Children } \\
\hline Son & $\begin{array}{l}\text { Dummy variable equal to } 1 \text { if the household head has at least one son, and } 0 \text { other- } \\
\text { wise }\end{array}$ \\
\hline Daughter & $\begin{array}{l}\text { Dummy variable equal to } 1 \text { if the household head has at least one daughter, and } 0 \\
\text { otherwise }\end{array}$ \\
\hline Son 12 & $\begin{array}{l}\text { Dummy variable equal to } 1 \text { if the household head has at least one son aged under } 13 \text {, } \\
\text { and } 0 \text { otherwise }\end{array}$ \\
\hline Son13_24 & $\begin{array}{l}\text { Dummy variable equal to } 1 \text { if the household head has at least one son aged between } \\
13 \text { and } 24 \text {, and } 0 \text { otherwise }\end{array}$ \\
\hline Son 25 & $\begin{array}{l}\text { Dummy variable equal to } 1 \text { if the household head has at least one son aged } 25 \text { or } \\
\text { above, and } 0 \text { otherwise }\end{array}$ \\
\hline Daughter12 & $\begin{array}{l}\text { Dummy variable equal to } 1 \text { if the household head has at least one daughter aged } \\
\text { under } 13 \text {, and } 0 \text { otherwise }\end{array}$ \\
\hline Daughter13_24 & $\begin{array}{l}\text { Dummy variable equal to } 1 \text { if the household head has at least one daughter aged } \\
\text { between } 13 \text { and } 24 \text {, and } 0 \text { otherwise }\end{array}$ \\
\hline Daughter25 & $\begin{array}{l}\text { Dummy variable equal to } 1 \text { if the household head has at least one daughter aged } 25 \\
\text { or above, and } 0 \text { otherwise }\end{array}$ \\
\hline
\end{tabular}

Other Independent Variables

Age

Wealth

Income

College

Household size

Migrant

Party membership

Riskaversion

Employee

Self-employed

Agriculture

Other job types

Retired

Geographic location

Urban

Policy area

High
Age of household head

Household's net wealth

Household's total income

Dummy variable equal to 1 if the household head has a college degree, and 0 otherwise

Size of the household

Dummy variable equal to 1 if the household head is a migrant, and 0 otherwise

Dummy variable equal to 1 if the household head is a party member, and 0 otherwise

Dummy variable equal to 1 if the household head prefers low-risk investments, and 0 otherwise

Dummy variable equal to 1 if the household head works as an employee, and 0 otherwise

Dummy variable equal to 1 if the household head is self-employed, and 0 otherwise

Dummy variable equal to 1 if the household head works in agriculture, and 0 otherwise

Dummy variable equal to 1 if the household head has another type of job, and 0 otherwise

Dummy variable equal to 1 if the household head is retired, and 0 otherwise

Dummy variable equal to 1 if the household is located in an urban area, and 0 otherwise

Dummy variable equal to 1 if the household is located in the three first-tier cities in China (Beijing, Shanghai and Guangzhou), and 0 otherwise

Dummy variable equal to 1 if the household is located in a province with high sex ratio (Gansu, Guangdong, Fujian, Hunan, Anhui, Hebei, Jiangsu, Shaanxi, Henan, Sichuan, Hubei, Guangxi, Jiangxi, Chongqing), and 0 otherwise

Note $*$ A household is assumed to have acquired an additional property between the 2011 and 2013 waves of the survey if it owned at least one house in both years and if the difference between the number of houses it owned in the two years is greater than or equal to 1 


\section{References}

Arrondel, L., Bartiloro, L., Fessler, P., Lindner, P., Mathä, T. Y., Rampazzi, C., Savignac, F., Schmidt, T, Schürz, M, \& Vermeulen, P. (2014). How do households allocate their assets? Stylised facts from the Eurosystem household finance and consumption survey. European Central Bank, Working Paper, No. 1722.

Brown, P. H., Bulte, E., \& Zhang, X. (2011). Positional spending and status seeking in rural China. Journal of Development Economics, 96(1), 139-149.

Brown, T., Lishman, R., Oxley, M., \& Turkington, R. (2008). Rapid evidence assessment of the research literature on the purchase and use of second homes. London: The National Housing and Planning Advice Unit.

Burgess, R., \& Zhuang, J. (2000). Modernisation and son preference. Development Economics discussion paper; DEDPS 29. Suntory and Toyota International Centres for Economic and Related Disciplines, London School of Economics and Political Science, London, UK.

Cao, Y., Chen, J., \& Zhang, Q. (2018). Housing investment in urban China. Journal of Comparative Economics, 46(1), 212-247.

Chamon, M. D., \& Prasad, E. S. (2010). Why are saving rates of urban households in China rising? American Economic Journal: Macroeconomics, 2(1), 93-130.

Chen, Y., Li, H., \& Meng, L. (2013). Prenatal sex selection and missing girls in China: Evidence from the diffusion of diagnostic ultrasound. Journal of Human Resources, 48(1), 36-70.

Choi, H., Lugauer, S., \& Mark, N. (2017). Precautionary saving of Chinese and US households. Journal of Money, Credit and Banking, 49(4), 635-661.

Cox, D., \& Stark, O. (2005). Bequests, inheritances and family traditions. Center for Retirement Research at Boston College, Working Paper No. 2005-09.

Di, Z. X., McArdle, N., \& Masnick, G. S. (2001). Second homes: What, how many, where and who. Harvard University Joint Center for Housing Studies, Research Note N-01-2.

Dijst, M., Lanzendorf, M., Barendregt, A., \& Smit, L. (2005). Second homes in Germany and the Netherlands: Ownership and travel impact explained. Tijdschrift voor economische en sociale geografie, 96(2), 139-152.

Feng, J., \& Zhou, Y. X. (2004). Intra-urban migration and correlative spatial behavior in Beijing in the process of suburbanization: based on 1000 questionnaires. Geographical Research, 23(2), 227-242.

Gallent, N., \& Tewdwr-Jones, M. (2018). Rural second homes in Europe: Examining housing supply and planning control. Routledge.

Gan, L., Yin, Z., Jia, N., Xu, S., Ma, S., \& Zheng, L. (2014). Data you need to know about China: Research report of China household finance survey, 2012. Berlin, Germany: Springer Science \& Business Media.

Glaeser, E., Huang, W., Ma, Y., \& Shleifer, A. (2017). A real estate boom with Chinese characteristics. Journal of Economic Perspectives, 31(1), 93-116.

Hall, C. M., \& Müller, D. K. (Eds.). (2004). Tourism, mobility, and second homes: Between elite landscape and common ground (Vol. 15). Channel View Publications.

Huang, Y. (2004). The road to homeownership: a longitudinal analysis of tenure transition in urban China (1949-94). International Journal of Urban and Regional Research, 28(4), 774-795.

Huang, Y., \& Yi, C. (2011). Second-home ownership in transitional urban China. Housing Studies, 26(03), 423-447.

Hui, E. C. M., \& Yu, K. H. (2009). Second homes in the Chinese Mainland under "one country, two systems": a cross-border perspective. Habitat International, 33(1), 106-113.

Knight, J., Shi, L., \& Quheng, D. (2010). Son preference and household income in rural China. Journal of Development Studies, 46(10), 1786-1805.

Lee, Y. J., \& Xiao, Z. (1998). Children's support for elderly parents in urban and rural China: Results from a national survey. Journal of Cross-Cultural Gerontology, 13(1), 39-62.

Lei, L., \& Pals, H. (2011). Son preference in China. Why is it stronger in rural areas? Population Review., $50(2), 27-46$.

Li, L., \& Wu, X. (2014). Housing price and entrepreneurship in China. Journal of Comparative Economics, 42(2), 436-449.

Li, L., \& Wu, X. (2017). The consequences of having a son on family wealth in urban China. Review of Income and Wealth, 63(2), 378-393.

Liu, C., \& Xiong, W. (2018). China's real estate market. National Bureau of Economic Research Working Paper No. 25297.

Müller, D. K. (2007). Second homes in the Nordic countries: Between common heritage and exclusive commodity. Scandinavian Journal of Hospitality and Tourism, 7(3), 193-201. 
National Bureau of Statistics (2010). Tabulation of the 2010 Population Census of the People's Republic of China, https://www.stats.gov.cn/tjsj/pcsj/rkpc/6rp/indexch.htm

Norris, M., \& Winston, N. (2010). Second-home owners: Escaping, investing or retiring? Tourism Geographies, 12(4), 546-567.

Paris, C. (2009). Re-positioning second homes within housing studies: Household investment, gentrification, multiple residence, mobility and hyper-consumption. Housing, Theory and Society, 26(4), 292-310.

Sierminska, E., \& Doorley, K. (2013). To own or not to own? Household portfolios, demographics and institutions in a cross-national perspective. IZA Discussion Paper No. 7734.

Song, L. (2000). Chapter 12. Gender effects on household resource allocation in rural China. Chinese Economy, 33(4), 68-95.

Wang, X. (2006). The second home phenomenon in Haikou, China (Master's thesis, University of Waterloo).

Wei, S. J., \& Zhang, X. (2011). The competitive saving motive: Evidence from rising sex ratios and savings rates in China. Journal of Political Economy, 119(3), 511-564.

Wei, S. J., Zhang, X., \& Liu, Y. (2017). Home ownership as status competition: Some theory and evidence. Journal of Development Economics, 127, 169-186.

World Bank (2006). Gender gaps in China: Facts and figures. Mimeograph. Available at: https://siteresour ces.worldbank.org/INTEAPREGTOPGENDER/Resources/Gender-Gaps-Figures\&Facts.pdf

Publisher's Note Springer Nature remains neutral with regard to jurisdictional claims in published maps and institutional affiliations. 